\title{
STRATEGI BISNIS PRIMEBIZ HOTEL SURABAYA MENGHADAPI PANDEMI COVID-19
}

\author{
Michelle Vebby Tanzil Salim \\ Program Studi Pariwisata, Universitas Ciputra Surabaya \\ Email: mvebby@student.ciputra.ac.id \\ I Dewa Gde Satrya \\ Dosen Program Studi Pariwisata, Universitas Ciputra Surabaya \\ Email: dewa.gde@ciputra.ac.id \\ Mohamad Yusak Anshori \\ Universitas Nahdlatul Ulama Surabaya \\ Email: yusak.anshori@unusa.ac.id
}

\begin{abstract}
The Covid-19 pandemic has a negative impact on the tourism and hospitality sector, one of which is PrimeBiz Hotel Surabaya (PHS). The lack of income for the hotel forces hotel management to think creatively and make the right decisions to maintain hotel operations. This study aims to describe the strategies that PHS has implemented during the Covid-19 pandemic. The research method was carried out qualitatively, the data were obtained through structured interviews with key informants from management, marketing experts, hospitality experts and PHS consumers. The conclusion of this study are; first, the Covid-19 pandemic makes PHS management have to weigh income and expenditure to be balanced. Second, the marketing strategy implemented by PHS is to maximize the use of social media for all employees. Third, the strategy carried out by PHS is to continue to implement a multitasking system, employees must be able to innovate and make adjustments to conditions that occur in the future.
\end{abstract}

Keywords: business strategy, hotel, Covid-19

\section{Pendahuluan}

Inegbedion (2020) menyatakan, pandemi Covid-19 telah membatasi aktivitas masyarakat dengan adanya lockdown hampir di berbagai negara. Indonesia tidak termasuk negara yang melakukan lockdown, melainkan mengambil kebijakan PSBB 
(Pembatasan Sosial Berskala Besar) seperti yang dilakukan di Jakarta dan Surabaya. Nasruddin \& Haq (2020) menyatakan, PSBB adalah strategi yang cukup efektif dalam menghambat dan memutus rantai penyebaran virus jika dibandingkan dengan lockdown.

Industri perhotelan sebagai bagian dari industri pariwisata, mengalami tekanan berat pada masa pandemi ini. Minimnya pemasukan tidak sebanding dengan jumlah pengeluaran. PSBB dan kekhawatiran tertular virus corona, menjadi alasan utama turunnya perjalanan wisata dan hunian hotel. PrimeBiz Hotel Surabaya sebagai salah satu industri perhotelan di Surabaya yang terdampak Covid-19, berupaya untuk bertahan di tengah situasi yang sulit saat ini.

Pada masa pandemi saat ini, setiap perusahaan melakukan pengaturan ulang strategi agar mampu bertahan. Anwar \& Hasnu (2017) menyatakan, strategi adalah cara yang digunakan oleh organisasi untuk menghadapi perubahan yang terjadi di dalam organisasi. Menurut Permatasari (2015), strategi bisnis hotel adalah cara yang dibuat oleh hotel dalam merencanakan sekaligus merealisasikan langkah-langkah strategis yang mampu meningkatkan posisi bersaing perusahaan di antara kompetitor hotel, membangun reputasi dan posisi yang diakui oleh konsumen, mampu memberi kepercayaan kepada konsumen atas kualitas dan pelayanan yang dimiliki oleh hotel, mempertahankan posisi bersaing perusahaan, serta mempengaruhi perkembangan jangka panjang.

Artikel ini melaporkan hasil penelitian tentang strategi bisnis PHS agar tetap bertahan dalam masa pandemi saat ini. Rumusan masalah dalam penelitian ini adalah bagaimana strategi yang diterapkan PHS dalam menghadapi pandemi Covid-19?

\section{Landasan Teori}

Strategi adalah cara yang digunakan oleh organisasi untuk menghadapi perubahan yang terjadi di dalam organisasi. Penentuan strategi meliputi tindakan 
yang diambil, isi strategi, dan proses di mana strategi ditentukan lalu diimplementasikan (Anwar \& Hasnu, 2017). Menurut Poernomo (2015), strategi adalah sekumpulan rencana yang luas, sistematis, dan terintegrasi yang menghubungkan keunggulan organisasi terhadap lingkungannya dan semuanya menerima manfaat baik secara ekonomi maupun non-ekonomi. Tetapi, strategi tidak dapat ditentukan secara langsung. Harus melalui beberapa pertimbangan. Menurut Brinks \& Ibert (2020), dengan pemahaman geografis tentang krisis, strategi harus disesuaikan dengan karakterisik dan kebutuhan spesifik dari setiap daerah. Menurut Bhaskara \& Filimonau (2021), pandemi Covid-19 menunjukkan kerentanan bisnis pariwisata dan perhotelan di Bali terhadap bencana. Karena itu, organisasi pembelajaran sangat penting untuk membangun bisnis pariwisata yang tahan bencana.

Anshori (2010: 142) menyatakan, kinerja pada hotel berbintang dapat ditingkatkan dengan menambah orientasi pasar, intellectual capital, orientasi pembelajaran, dan inovasi, karena 4 variabel tersebut mempengaruhi kinerja secara bersamaan dengan persentase sebesar $76.4 \%$.

\section{Orientasi pasar}

Merupakan kemampuan perusahaan dalam memenuhi keinginan konsumen berdasarkan informasi pasar yang diperoleh. Implementasi yang dapat dilihat secara nyata adalah bagaimana suatu hotel berbintang selalu menyediakan paket untuk dipromosikan pada acara tertentu. Misalnya, paket untuk perayaan akhir tahun, hari raya, valentine, pernikahan dan ulang tahun. Melalui acara-acara seperti ini bisa disimpulkan jika hotel berbintang selalu ingin mendapatkan konsumen melalui paket yang telah disediakan dan sesuai dengan keinginan konsumen. 


\section{Intellectual capital}

Dalam suatu perusahaan atau organisasi, pasti dituntut untuk berinovasi dalam menciptakan produk baru dan meningkatkan kualitas produk agar bisa bertahan dan memenangkan persaingan. Untuk melakukan hal ini dibutuhkan perubahan dalam struktur dan kebiasaan di dalam lingkungan perusahaan dan manajemen. Intellectual capital adalah hal yang dibutuhkan untuk melakukan perubahan tersebut, yang merupakan ilmu pengetahuan dan sumber daya yang dimiliki perusahaan tetapi tidak memiliki wujud fisik. Implementasi yang bisa dilihat secara nyata adalah banyaknya pengetahuan yang ada di bagian departemen dalam suatu perusahaan, misalnya memiliki kompetensi dalam mengelola perusahaan, kemampuan dalam berinovasi, dan memecahkan suatu masalah dalam perusahaan. Jika intellectual capital yang dimiliki setiap individu dapat bersinergi dan berjalan bersama-sama, maka kinerja yang dihasilkan juga maksimal.

\section{Orientasi pembelajaran}

Merupakan kemampuan perusahaan atau organisasi dalam menjadikan informasi pasar yang diperoleh seluruh anggota organisasi sehingga seluruh anggota memiliki pemahaman yang sama atas kebutuhan konsumen. Implementasi yang bisa dilihat secara nyata adalah sebelum paket yang dibuat dipublikasikan ke masyarakat, hotel akan melakukan pelatihan internal agar seluruh karyawan memahami paket yang akan dijual. Pelatihan ini diprioritaskan kepada karyawan yang terlibat secara langsung dengan penjualan paket, sehingga mereka mengerti saat ada konsumen yang bertanya mengenai paket tersebut.

\section{Inovasi}

Merupakan cara untuk mencegah agar tidak terjadi hambatan saat berusaha untuk memenangkan persaingan. Tanpa inovasi, suatu perusahaan atau organisasi tidak akan bisa berkompetisi dengan baik, serta tidak memiliki nilai tambah untuk 
mencapai keuntungan yang lebih besar. Permintaan konsumen pasti bisa berubah sewaktu-waktu sesuai tren, maka dari itu suatu perusahaan atau organisasi harus mampu berinovasi untuk membuat barang baru atau berinovasi terhadap hal-hal yang sudah ada.

Wardani \& Khoiriyah (2018) menyatakan, strategi bisnis adalah strategi yang diterapkan perusahaan untuk beradaptasi menghadapi lingkungan yang kompetitif. Wibowo \& Hariyati (2018) menyatakan, strategi bisnis mampu menunjukkan entitas terhadap hasil yang ingin diraih dan menentukan langkah yang akan diambil untuk memenuhi kebutuhan pasar guna mencapai tujuan utama. David (dalam Rachmarwi, 2016) menyatakan, strategi bisnis bisa dalam bentuk perluasan geografi, diversifikasi, akuisisi, pengembangan produk, penetrasi pasar, rasionalisasi karyawan, divestasi, likuidasi, dan joint venture. Miles \& Snow (dalam Anwar \& Hasnu, 2017), menyatakan, strategi prospector, defender, analyzer adalah tiga strategi bisnis yang dapat terus bertahan, menunjukkan perbedaan, namun konsisten dan repetitif dalam menganalisis lingkungan sekitar, target market yang luas, inovasi dan cara menggunakan teknologi dalam memecahkan masalah bisnis, teknis, dan administratif. Jika tiga strategi ini diletakkan dalam suatu rangkaian, maka strategi defender dan prospector berada di ujung, dan strategi analyzer akan berada di tengah sebagai penyeimbang. Sedangkan strategi reactor adalah strategi keempat dan tidak termasuk di dalam strategi yang dapat bertahan.

Saragih \& Elisabeth (2020) menyatakan, strategi bisnis bertahan adalah strategi yang dapat diimplementasikan agar suatu perusahaan dapat bertahan dalam situasi tertentu. Ada beberapa strategi yang dapat diterapkan dalam suatu perusahaan agar dapat bertahan di pandemi Covid-19:

1. Memberikan ruang kepada masyarakat untuk melihat kembali produk-produk yang dihasilkan oleh hotel 
2. Memperhatikan manajemen cashflow selama masa pandemi Covid-19 sebagai langkah preventif

3. Membatasi aktivitas dengan mengatur jam operasional sehari-hari untuk efisiensi biaya

4. Menerapkan strategi diversifikasi tidak terkait dari usaha sebelumya

5. Menerapkan manajemen persediaan untuk menghemat biaya produksi, dan memastikan lancarnya proses keluar masuk suatu produk

\section{Metode Penelitian}

Peneliti menggunakan metode kualitatif untuk mengetahui strategi apa saja yang diterapkan di PrimeBiz Hotel Surabaya dalam menghadapi pandemi saat ini. Klenke (2016: 33) menyatakan, penelitian yang menggunakan metode kualitatif adalah metode yang menghasilkan banyak data secara mendetail dari beberapa orang dan kasus yang memang terpilih, melalui jawaban yang mendalam dan mendetail berdasarkan pada pertanyaan dan deskripsi situasi, acara, interaksi, dan tingkah laku. Beberapa penelitian kualitatif menggunakan orientasi metode yang ketat dan mengartikan penelitian kualitatif sebagai alat penelitian khusus, seperti studi kasus, focus group, sejarah, wawancara terstruktur, observasi, dan analisis isi dari berbagai tulisan.

Dalam penelitian ini, peneliti menggunakan teknik penjaringan data purposive sampling. Menurut Garg (2019), purposive sampling adalah teknik yang digunakan secara luas dalam penelitian di mana narasumber atau informan dipilih oleh peneliti berdasarkan kriteria yang dibutuhkan. Bisa disimpulkan bahwa informan yang dipilih harus sesuai dengan kriteria yang ditentukan oleh peneliti, yang memiliki kredibilitas untuk menjawab permasalahan dari penelitian. Informan dalam penelitian ini adalah Operation Manager dan Marketing Manager PrimeBiz Hotel 
Surabaya, ahli industri perhotelan, ahli marketing dan konsumen PrimeBiz Hotel Surabaya.

Tabel 1. Profil Informan

\begin{tabular}{|c|c|c|c|c|}
\hline No. & Nama & $\mathbf{P} / \mathbf{W}$ & Pekerjaan & Coding \\
\hline 1. & Ella & $\mathrm{W}$ & $\begin{array}{l}\text { Operational Manager PrimeBiz } \\
\text { Hotel Surabaya }\end{array}$ & $\mathrm{E}$ \\
\hline 2. & Andik Setiawan & $\mathrm{P}$ & $\begin{array}{l}\text { Marketing Manager PrimeBiz } \\
\text { Hotel Surabaya }\end{array}$ & AS \\
\hline 3. & Bambang Hermanto & $\mathrm{P}$ & $\begin{array}{l}\text { Direktur MTM National } \\
\text { Hospitality Certification }\end{array}$ & $\mathrm{BH}$ \\
\hline 4. & Sandy Wahyudi & $\mathrm{P}$ & $\begin{array}{l}\text { President Director SLC } \\
\text { Marketing, INC. }\end{array}$ & SW \\
\hline 5. & Eni Widyawati & W & $\begin{array}{l}\text { Kepala SMK Kesehatan Adi } \\
\text { Husada Malang }\end{array}$ & EW \\
\hline 6. & Ratih & W & $\begin{array}{l}\text { Sekretaris SMK Kesehatan Jawa } \\
\text { Timur }\end{array}$ & $\mathrm{R}$ \\
\hline
\end{tabular}

Sumber: Peneliti (2021)

\section{Hasil Penelitian}

Di masa pandemi Covid-19, kondisi perhotelan di Indonesia cukup memprihatinkan. Turunnya okupansi hotel yang drastis membuat banyak hotel tutup karena tidak mampu membayar biaya operasional. Hal ini membuat banyak karyawan yang harus dikeluarkan atau dirumahkan oleh perusahaan, karena hotel tidak memiliki cukup banyak pemasukan untuk membayar gaji karyawan.

"Hampir semua orang tidak melakukan perjalanan, baik itu antar kota maupun antar negara, sehingga sangat berpengaruh terhadap occupancy hotel. Orang cenderung di 
rumah, jadi efeknya sangat luar biasa waktu itu, karena pada bulan maret saya ingat, akhir april, pada bulan april itu sudah langsung menukik" (E-8, E-2)

"Kondisi perhotelan sangat berat. Kalau saya bicara dari sisi SDM, hampir semua hotel nggak bisa mencari SDM yang ideal. Jadi itu terbentuk dari, pertama dari kunjungan yang ada ke Surabaya, kalo saya bicara Surabaya itu kan sedikit, apalagi dulu pernah banget dibatasi. Notabene orang yang menginap di hotel rata-rata adalah pengguna transportasi udara. Rata-rata, nggak semuanya ya. Tapi itu bisa kita tarik garis, jumlah arrival yang ada di Juanda sama tingkat hunian hotel itu bisa dibandingkan, bisa dilihat trendnya. Kalo arrival naik, tingkat hunian hotel juga naik, rata-rata seperti itu." (AS-9, F-2)

Berdasarkan wawancara yang didapatkan dari pihak eksternal dan internal PHS, di masa pandemi Covid-19 banyak hotel yang tutup karena okupansi yang menurun $60 \%$ hingga $80 \%$. Perkiraan hanya 10\% hotel yang masih buka, sedangkan 90\% hotel harus tutup karena PSBB. Pemerintah juga mencegah adanya kegiatan yang melibatkan banyak orang di dalam satu ruangan. Hal-hal seperti ini yang menyebabkan okupansi hotel dan pendapatan hotel menurun drastis, kepercayaan konsumen terhadap hotel juga ikut menurun. Tetapi seiring berjalannya waktu, pemerintah memberlakukan "new normal", yang artinya aktivitas mulai dapat dilakukan seperti biasanya namun dengan beberapa ketentuan baru. Banyak perusahaan seperti perhotelan, membuat beberapa strategi baru yang mampu mendapatkan kepercayaan dari konsumen, sehingga okupansi bisa naik sedikit demi sedikit.

"Nah new normal ini, itu sudah mulai buka, kira-kira 2 bulan yang lalu itu sudah mulai banyak yang buka. Tidak 100\%, tetapi bulan Desember ini akan buka semua kalo saya amati itu, seperti itu. Nah, pada saat 2 bulan, new normal itu, itu occupancy sudah mulai bagus. Kira-kira 30-40\%, sebelumnya itu hanya 10\% kemudian 20\%, kalo sekarang ini sudah 3040\%, jadi seperti itu" (BH-6, G-2) 
Dalam menentukan suatu tindakan dalam perusahaan, biasanya dibutuhkan juga keputusan dari beberapa stakeholder yang berkaitan. Dengan kerterkaitan stakeholder internal maupun eksternal dengan perusahaan tersebut, maka mereka memiliki hak dan tanggung jawab untuk memberikan pendapat dan keputusan dari perspektif yang dimiliki oleh masing-masing individu, lalu didiskusikan bersama dan menentukan jalan tengah.

Keputusan stakeholder sangat penting dalam menentukan suatu tindakan. Keputusan harus dibuat dengan cepat dan datang dengan perspektif baru, sehingga tidak didahului oleh perusahaan lain. Setiap hotel akan berpikir bagaimana caranya untuk survive di tengah pandemi, terutama dalam hal menyeimbangkan pengeluaran yang besar dengan pemasukan yang kecil.

Pandemi Covid-19 membuat banyak perusahaan harus membuat strategi baru yang dapat menyesuaikan keadaan, seperti yang terjadi pada perhotelan. Berikut ini adalah strategi yang dilakukan PHS:

\section{Pelatihan karyawan}

Di masa pandemi Covid-19, karyawan diberikan wawasan seputar Covid-19, misalnya penyebab penularan, cara memutus rantai penularan, dan protokol kesehatan yang harus dilakukan untuk mencegah terjadinya penularan.

"Kalo pelatihan khusus nggak ada ya, tetapi langsung pada saat melakukan itu. Misalnya, nganter makanan ke kamar atau menyediakan makanan pada saat buffet ya harus pake hand gloves seperti itu." (E-26, E-4)

"Ada pelatihan HACCP, most important untuk hospitality industry" (BH-27, G-5)

2. Menjual voucher

Di awal masa pandemi, semua orang harus bekerja dari rumah dan menjadi kurang efektif, sehingga pendapatan perusahaan pun ikut menurun. Banyak 
karyawan yang mengalami pengurangan gaji dan bahkan dirumahkan untuk sementara. Harga untuk menginap di hotel juga bisa dibilang cukup mahal. Hal ini membuat hotel pada masa new normal ini, memberikan promo berupa voucher untuk menginap di hotel dengan expiry date yang cukup lama, sehingga konsumen bisa memilih tanggal untuk melakukan staycation. Harganya juga menjadi sangat murah.

3. Mengatur operasional untuk menyeimbangkan minimum revenue dengan expenses

Di masa pandemi, pembaharuan dalam pengaturan operasional perlu dilakukan. Terutama pengaturan operasional seperti sumber daya manusia, listrik, dan air. Turunnya okupansi secara drastis yang disebabkan oleh Covid-19 menyebabkan pendapatan hotel juga turun drastis. Sementara itu, biaya yang dikeluarkan sama, bahkan lebih dari biasanya karena harus membeli alat-alat untuk protokol kesehatan seperti, alkohol, hand sanitizer, masker, acrylic, alat pengukur suhu tubuh, dan gloves. Hasil wawancara manajemen PHS memberikan informasi adanya pengurangan karyawan untuk mengurangi biaya yang besar dan memanfaatkan karyawan semaksimal mungkin dengan melakukan multitasking. Karyawan yang biasanya in-charge di dalam satu pekerjaan saja, sekarang harus bisa merangkap di jobdesk lainnya.

Tetapi, ada beberapa biaya yang memang tidak bisa dipangkas, misalnya biaya abonemen, merupakan biaya operasional hotel minimum sehingga hotel tetap bisa beroperasi. Biaya listrik dan air juga dikurangi dengan cara memaksimalkan kamar hanya di beberapa lantai, sisanya dimatikan. Selain itu, ada spare money yang digunakan sebagai biaya tak terduga. Hal ini wajib dimasukkan ke dalam perhitungan keuangan, karena walaupun sekecil apapun resikonya, pasti tetap ada resiko yang bisa terjadi sewaktu-waktu. Membayar gaji karyawan adalah suatu keharusan, maka dari itu cara yang paling umum dilakukan oleh banyak perusahaan saat ini adalah pengurangan karyawan. 
Di awal pandemi, PHS juga menutup restoran karena tidak boleh mengadakan breakfast, lunch dan dinner dengan sistem buffet. Semua makanan konsumen beralih ke in-room dining, atau makanan diantar ke kamar.

"Kalo buffet itu kita hanya buka pada saat breakfast. Jadi gini, pada saat bulan April itu buffet kita tutup, full. Karena anjuran dari pemerintah juga gitu. Jadi tidak ada meskipun untuk breakfast, lunch, dinner, semua kita tutup dan kita alihkan ke in-room dining. Jadi, tamu yang menginap yang mendapatkan breakfast, kita kirim breakfastnya ke kamar. Atau ada pesanan misalnya untuk makan siang atau malem kita kirim ke kamar. Semua standartnya seperti itu. Itu berjalan sampai dengan bulan Agustus. Jadi Agustus itu baru kita buka, karena permintaan tamu juga ini" (E-22, E-3)

4. Bekerjasama dengan sektor kesehatan di Surabaya

Pada masa pandemi, banyak perusahaan-perusahaan seperti hotel bekerjasama dengan sektor kesehatan di daerah masing-masing. Tujuannya adalah jika ada tamu yang memiliki suhu tubuh yang tinggi atau merasa tidak enak badan, akan dilarikan langsung ke rumah sakit yang bekerjasama dengan perusahaan atau hotel tersebut untuk dicek atau dilakukan perawatan. Terkait hal itu, dalam rangka memutus mata rantai penularan, semua orang wajib menerapkan protokol kesehatan yang sudah dibuat oleh pemerintah. Banyak perusahaan seperti hotel dan restoran menerapkan protokol kesehatan dengan ketat lalu dipublikasikan sehingga mampu mendapatkan kepercayaan dari masyarakat, sehingga mereka merasa aman saat menginap di hotel.

"Secara berkala housekeeping membersihkan kamar, setelah membersihkan ya langsung kita semprot disinfektan sehingga ketika tamu kembali lagi ke hotel, kamar sudah dalam kondisi higienis" (E-19, E-3) 
"Setiap 5-10 menit sekali kita harus menerapkan HACCP. Kita harus cuci tangan, harus pake hand sanitizers, dan setiap area public kita siapkan hand sanitizer" (AS-14, F-3)

Hasil wawancara yang didapatkan dari konsumen, memberi bukti bahwa PHS menerapkan protokol kesehatan di area hotel. Hal tersebut terbukti mampu membangun kepercayaan konsumen kepada hotel dan membuat konsumen merasa aman untuk tinggal.

"Protokol kesehatan, sudah bagus sih. Soalnya kan di depan juga sudah dikasih untuk tempat cuci tangan, kemudian kita juga selalu dikasih. Dicek suhu badan pake thermo gun, kemudian kita kalo makan itu juga ada sarung tangannya. Terus, hand sanitizer juga tersedia dimana-mana, apalagi kalo saya event gitu, di setiap ruangan itu juga ada hand sanitizer. Ya lengkap sih, kalo menurut saya sudah sesuai" (EW-17, I-3)

"Kita di dalam ruangan meeting pun juga disediakan sarung tangan plastik, sehingga apabila temen-temen itu pingin.., kan kita coffee break makan siang semuanya kan box ya, karena kan pandemi saya nggak mau buffet, jadi kita sudah box semua, ya kalo mau pake sarung tangan plastik itu langsung sudah disediakan." (EW-19, I-3)

"Beberapa kali saya di PrimeBiz itu selama pandemi, memang protokol kesehatan mulai kita dari masuk, kemudian di setiap sudut ruangan itu kan ada hand sanitizer, kemudian sebelum kita masuk ruangan itu kita di cek suhu, seperti itu. Kemudian kalo hotel PrimeBiz memang daridulu terkenal kebersihannya, jadi makanya kebersihannya itu menurut saya kalo dibandingan hotel lain itu nggak diragukan, gitu. Makanya, kalo setiap ke Surabaya itu pasti ke Hotel PrimeBiz saya menginapnya, walaupun misalnya nggak ada acara seperti itu, saya nggak ada acara meeting di Hotel PrimeBiz, tapi tetep nginepnya itu kita di Hotel PrimeBiz. Karena menurut saya kebersihannya sih, kebersihan dari kamarnya juga itu menurut saya masih bagus dibandingkan yang lain." (R-10, J-2) 


\section{Covid secure certified}

Sertifikasi bebas Covid-19 dapat membantu hotel dalam mendapatkan kepercayaan dari konsumen. Hotel yang mendapatkan sertifikasi tersebut dinyatakan menerapkan protokol kesehatan dengan baik dan bebas dari Covid-19. Sertifikasi bebas Covid-19 bisa didapatkan dengan beberapa langkah yang harus dilalui oleh hotel, yaitu pengajuan formulir, lalu pihak dari lembaga sertifikasi akan datang ke hotel untuk melakukan pengecekan. Jika sudah terbukti aman dan mampu menerapkan protokol kesehatan dengan baik, maka hotel tersebut akan mendapatkan sertifikasi bebas Covid-19. PHS memiliki sertifikasi ini, dan terbukti berhasil meningkatkan occupancy dan kepercayaan konsumen untuk datang dan menginap.

\section{Fleksibilitas harga}

Penyesuaian harga sangat dibutuhkan oleh banyak orang di masa pandemi Covid-19 ini. Banyak hotel yang saling bersaing menurunkan harga demi mendapatkan konsumen di tengah-tengah turunnya okupansi hotel. Tidak hanya harga kamar, tetapi juga harga untuk peminjaman meeting room. Harga biasanya didiskusikan terlebih dulu antara pihak hotel dan konsumen. Pihak hotel tidak bisa asal menentukan harga, harus ada penyesuaian antara pendapatan yang dibutuhkan, fasilitas yang diberikan dan keinginan konsumen.

"Setelah itu harga, nggak bisa idealis 'hargaku harus segini' nggak bisa. Teori permintaan kita pake, nggak ada pasar ya kita harus turunkan harga dong. Jadi harga harus turun, mau nggak mau harga harus turun, kita hitung ulang lagi, kita kumpul 'mau jual berapa?

Kalau jual segini nggak mungkin laku. Kita lanjut operasional dulu atau nego harga tertinggi tapi nggak jalan semuanya, ya akhirnya bertahap. Jadi pertama buka harga murah banget waktu bulan April. Sekarang udah naik, sekarang aku udah promo paling murah sekitar Rp 380.000 sudah. Padahal dulu awal masih Rp 225.000, jadi kan bertahap." (AS24, F-5) 
Berdasarkan wawancara dengan manajemen PHS, di masa pandemi Covid-19 ini memang perlu menyesuaikan dengan pasar. Mengingat okupansi turun drastis, maka hotel harus mencari Cara agar hotel bisa pelan-pelan terisi, sekaligus mendapatkan kepercayaan dari masyarakat. Tidak hanya dari pihak internal PHS, hasil wawancara konsumen dari hotel tersebut juga membuktikan bahwa PHS benarbenar melakukan penyesuaian harga yang sesuai dengan kebutuhan konsumen.

"Kami dari segi harga selalu dikasih kemudahan-kemudahan, jadi ibaratnya harga pax normalnya sekian gitu kan, kami tinggal menyebutkan 'mas, saya anggarannya cuma ada sekian, bisa disesuaikan?' Jadi banyak kemudahan-kemudahan." (EW-11, I-2)

\section{Strategi marketing}

Work from home membuat kegiatan marketing tidak bisa maksimal. Yang biasanya bisa melakukan sales call sekarang hanya bisa melalui social media. Pihak hotel harus memikirkan cara pemasaran yang baru agar masyarakat mau menginap di hotel dan membuat okupansi naik secara bertahap. Berikut adalah strategi yang dilakukan:

Strategi yang sangat penting saat ini adalah membangun rasa percaya pada konsumen. Salah satu hal yang membuat okupansi menurun adalah rasa takut konsumen untuk menginap di tempat umum, di mana kemungkinan tertular cukup tinggi. Tugas yang paling penting adalah mempublikasikan kepada masyarakat jika hotel sudah menerapkan standar protokol kesehatan yang sudah ditetapkan oleh pemerintah dan bebas dari Covid-19.

"Strategi marketing sekarang lebih kepada penerapannya, bagaimana bukan pricing, promosi saja, harganya diskon gitu ya. Tetapi memberi jaminan bahwa karyawan saya melayani anda, bebas Covid-19. Semua peralatan yang saya pakai dikantor saya atau di toko saya ini semua saya steril. Ya itu yang lebih memberi garansi sih, itu yang membuat orang percaya untuk datang ke tokonya atau ke lokasi hotelnya." (SW-4, H-2) 
Social media yang dimiliki oleh karyawan hotel bisa dijadikan sebagai media marketing. Masyarakat kita banyak yang menggunakan social media, apalagi karena work from home, social media adalah hiburan terdekat yang bisa dinikmati oleh semua orang. Artinya, banyak orang sering membuka social media setiap harinya, sehingga besar kemungkinannya bagi banyak orang untuk melihat promo yang dibuat oleh hotel.

"Strateginya karena waktu awal pandemi ya, sampe saat ini kita aktivitas yang direct langsung sales call itu sulit, banyak perkantoran yang tutup, banyak yang WFH, ya otomatis lewat media sosial." (AS-21, F-5)

"Ya kita share aja, share ke semua booker. Kan semua marketing punya account istilahnya, jadi dia punya Nama dan asal perusahaan, ya kita share promo-promo. Rutin kita share. Nanti itu, setelah share itu kita nggak nge share di orang marketing aja, setiap minggu kita ada promo atau ada jual kamar yang package gitu, seluruh karyawan harus terlibat." (AS22, F-5)

"Karena semua karyawan adalah marketing. Kalo misalnya datang ke hotel nggak ngerti 'pak saya mau ke restroom', kamu nanya ke security, dia masih baru, kan kamu nggak peduli. 'Lo saya orang baru pak, saya nggak tau'. Yang penting dia nanya di mana. Jadi seluruh karyawan itu marketing, bisa jadi marketing. Jadi semua harus ngeshare, kalo pas dapet nggak dapet terserah dia. Yang penting brand ini bisa muncul dimana-mana tetep 'PrimeBiz maneh, PrimeBix maneh'. Karena kita ya kuat brand. Kalo kamu lihat dari jauh $M c D$ 'ohh $M c D^{\prime}$. Kamu dari jauh liat 'oh sepatunya Nike ya'. Dan itu bisa terbentuk, pengenalan yang secara intens, dan itu kita libatkan." (AS-23, F-5)

"Prinsip kita di marketing adalah harus marketing sama experiental marketing, jadi kita mendatangkan tamu, terus jujur, adanya hotel kami ya ini, ruangan kita cuma kecil ini. Jadi kita disini pertama adalah di booker sudah ada positioning bahwasannya PrimeBiz Hotel itu nggak lebay. Itu keuntungan buat kami pertama. Yang tak liat di.., kemarin sebelum anu 
saya buat SWOT Analysis untuk ini sebelum tak SWOT Analysis itu. Jadi anggapan di luar, Hotel PrimeBiz ini adalah apa adanya dan itu yang dibutuhkan saat ini. Jadi misal jangan kaget kalo misal liat foto-foto kamarku itu jelek. Jadi aku nggak mau kalo orang, karena teori kepuasan adalah saat apa yang dijanjikan 90, orang ternyata kok dapet 80, apapun itu yang terjadi dia nggak akan puas. Tapi, saat aku nunjukkan hal, ya apa adanya ini, kamar kami misalkan nggak sebagus ini, tapi ternyata dia waktu kesini dapet ekspektasinya sudah rendah, dapet 80 aja dia puas." (AS-20, F-4)

\section{Kesimpulan dan Saran}

\section{Kesimpulan}

Kesimpulan dari penelitian ini adalah sebagai berikut:

1. Pandemi Covid-19 membuat manajemen PHS harus menimbang pendapatan dan pengeluaran agar menjadi seimbang. Pengurangan SDM dan pengaturan operasional terhadap biaya listrik dan air juga dilakukan, sehingga hotel masih bisa mencapai minimum revenue untuk menutup biaya operasional yang harus dibayar.

2. Strategi marketing yang diterapkan PHS adalah dengan memaksimalkan penggunaan social media dari seluruh karyawan. Setiap karyawan hotel harus mempublikasikan promo-promo yang ada di hotel di social media masing-masing.

3. Strategi yang dilakukan PHS selanjutnya adalah tetap melakukan sistem multitasking, karyawan harus bisa berinovasi dan melakukan penyesuaian kondisi yang terjadi di masa mendatang. 


\section{Saran}

1. Saran bagi PHS

Promosi di social media, khususnya di Instagram, dapat digunakan lebih aktif untuk menunjukkan penerapan protokol kesehatan yang dilakukan secara konsisten di hotel, kerja sama hotel dengan rumah sakit dan berbagai hal yang menunjukkan kesiapan PHS dalam menerima tamu di masa pandemi Covid-19 ini.

2. Saran bagi peneliti selanjutnya

Bagi peneliti selanjutnya, disarankan untuk memperdalam setiap indikator, atau juga bisa menggunakan indikator lain yang menarik untuk diteliti sehingga data yang didapatkan bisa lebih dalam dan meluas.

\section{Daftar Pustaka}

Anshori, M. Y. (2012). Improving the Restaurant Product Sale: A Case Study at a Hotel in Surabaya. International Research Journal of Business Studies, Vol. 5 No. 3.

Anshori, M. Y. (2019). “Analisis Turnover Intention Pada Karyawan Primebiz Hotel Surabaya", Jurnal Ekonomi dan Pariwisata, Vol. 14. No. 1. pp. 66-72.

Anshori, M. Y., Karya, D. F., Fatmasari, D., Herlambang, T. (2020), “A Study of Revisit Intention: Beach Image, Beach Uniqueness, Beach Authenticity, Attraction, and Satisfaction in Lombok Beach Nusa Tenggara Barat", TEST Engineering $\mathcal{E}$ Management Journal, Vol. 83 (May-June), pp. 2988-2996.

Anshori, Y. (2005). “Analisis Keunggulan Bersaing Melalui Penerapan Knowledge Management Dan Knowledge Based-Strategy di Surabaya Plaza Hotel”, Jurnal Manajemen Perhotelan, Vol. 1. No. 2. pp. 39-53.

Anshori, Y. (2010). Manajemen Strategi Hotel. Cetakan kedua, Surabaya: Putra Media Nusantara.

Anshori, Y. Langner, V. (2007). The Importance of Customer Satisfaction and Supreme Service Provision in The Hotel Industry. A Case Study of Surabaya Plaza Hotel. Jurnal Manajemen Perhotelan, Vol. 3. No. 1. pp. 18-25. 
Anwar, J., \& Hasnu, S. (2017). Strategic patterns and firm performance: comparing consistent, flexible and reactor strategies. Journal of Organizational Change Management, 30(7), 1015-1029.

Astina, M. A., \& Artani, K. T. B. (2017). Dampak perkembangan pariwisata terhadap kondisi sosial dan ekonomi masyarakat Sanur. Jurnal Ilmiah Hospitality Management, 7(2), 141-146.

Badan Pusat Statistik Negara Indonesia. (2020). Jumlah Kunjungan Wisatawan Mancanegara Per-bulan ke Indonesia Menurut Pintu Masuk Tahun 2017-2020. https://www.bps.go.id/dynamictable/2018/04/05/1296/jumlah-kunjunganwisatawan-mancanegara-per-bulan-ke-indonesia-menurut-pintu-masuk2017-2020.html

Baum, T., Mooney, S.K.K., Robinson, R.N.S. and Solnet, D. (2020), "COVID-19's impact on the hospitality workforce - new crisis or amplification of the norm?", International Journal of Contemporary Hospitality Management, Vol. 32 No. 9, pp. 2813-2829.

Bhaskara, Gde Indra \& Vilimonau, Viachaslau. (2021), “The COVID-19 pandemic and organisational learning for disaster planning andmanagement", Journal of Hospitality and Tourism Management, 19 January 2021 (online version)

Brinks, V. and Ibert, O. (2020), "From corona virus to corona crisis: the value of an analytical and geographical understanding of crisis", Tijdschrift Voor Economische en Sociale Geografie, Vol. 111 No. 3, pp. 275-287.

Garg, S. (2019), "Research Methodology", HR Initiatives in Building Inclusive and Accessible Workplaces, Emerald Publishing Limited, pp. 61-83.

Huda, A.M. and Martanti, D.E., (2018). Pengantar Manajemen Strategik. Jayapangus Press Books.

Hung, K.K.C., Mark, C.K.M., Yeung, M.P.S. et al. (2018). The role of the hotel industry in the response to emerging epidemics: a case study of SARS in 2003 and H1N1 swine flu in 2009 in Hong Kong. Global Health 14, 117.

Ida, R., (2018). Etnografi Virtual Sebagai Teknik Pengumpulan Data Dan Metode Penelitian. The Journal of Society and Media, 2(2), pp.130-145.

Inegbedion, H.E. (2020), "COVID-19 lockdown: implication for food security", Journal of Agribusiness in Developing and Emerging Economies, Vol. ahead-of-print No. ahead-of-print.

Jones, P. and Comfort, D. (2020), "The COVID-19 crisis and sustainability in the hospitality industry", International Journal of Contemporary Hospitality Management, Vol. ahead-of-print No. ahead-of-print. 
Klenke, K. (2016), "Qualitative Research as Method", Qualitative Research in the Study of Leadership, Emerald Group Publishing Limited, pp. 31-55.

Mulyadi, S., (2019). Analisis Implementasi Fungsi Pengorganisasian Dalam Pengelolaan Sumber Daya Insani di KSPPS Mitra Insan Mandiri (Doctoral dissertation, Universitas Siliwangi).

Nasruddin, R., \& Haq, I. (2020). Pembatasan Sosial Berskala Besar (PSBB) dan Masyarakat Berpenghasilan Rendah. SALAM: Jurnal Sosial dan Budaya Syari, 7(7), 639-648.

Nilamsari, N., (2017). Memahami studi dokumen dalam penelitian kualitatif. WACANA: Jurnal Ilmiah Ilmu Komunikasi, 13(2), pp.177-181.

Pereira de Oliveira, J., Torres Tricárico, L., de Mello Rossini, D. and Tomelin, C.A. (2019), "Concepts of hospitality and its application in the built space: Genesis and evolution of urban hospitality in tourist Brazilians destinations", Journal of Hospitality and Tourism Insights, Vol. 3 No. 2, pp. 155170.

Permatasari, D.E., (2015). Penentuan Strategi Bisnis Manajemen Hotel Dalam Menghadapi Persaingan (Studi Kasus di Quds Royal Hotel Surabaya). Jurnal Administrasi Bisnis, 27(1).

Poernomo, D., (2015). Manajemen Strategis Smart city. In Seminar Nasional Riset Terapan (SENASSET).

Romandhona, D. (2016). Pengelolaan, Partisipasi, Potensi dan City Branding sebagai Upaya Pengembangan Industri Pariwisata di Kota Surabaya. Universitas Airlangga.

Rukajat, A., (2018). Pendekatan Penelitian Kualitatif (Qualitative Research Approach). Deepublish.

Saragih, R., \& Elisabeth, D. M. (2020). Kewirausahaan Sosial Dibalik Pandemi Covid19: Penelusuran Profil dan Strategi Bertahan. Jurnal Manajemen, 1(1), 47-56.

Sridevi, K.B. (2020), "Filling the quality gaps for a futuristic management education", Journal of Economic and Administrative Sciences, Vol. ahead-of-print No. ahead-of-print.

Suliyanto, S.E. and MM, S., (2017). Metode Penelitian Kuantitatif.

Supraptiningsih, U., (2016). Karakteristik Pengemis Perempuan Di Kecamatan Tlanakan Kabupaten Pamekasan. NUANSA: Jurnal Penelitian Ilmu Sosial dan Keagamaan Islam, 13(2), pp.357-382. 
Todorov, K. and Akbar, Y.H. (2018), "Basics of Strategic ManagementEtihad Rail: A New Way to Change a Business Landmark in the United Arab EmiratesCase Study: Inchcape plc. Part 3", Strategic Management in Emerging Markets, Emerald Publishing Limited, pp. 109-161.

Utama, I.G.B.R. and SE, M., (2015). Pengantar Industri Pariwisata. Deepublish.

Vivas, V. and Villar, M. (2020), "Strategic responses to the COVID-19 pandemic in Pacific Alliance countries", Management Research, Vol. ahead-of-print No. ahead-of-print.

Wardani, D.K. and Khoiriyah, D., (2018). Pengaruh strategi bisnis dan karakteristik perusahaan terhadap penghindaran pajak. Akuntansi Dewantara, 2(1), pp.25-36.

Wibowo, H.W. dan Haryati, (2018). Pengaruh Strategi Bisnis Prospector Terhadap Kinerja Keuangan yang Dimediasi oleh Sistem Informasi Akuntansi Manajemen pada Perusahaan Jasa Perhotelan di Surabaya, Jurnal Akuntansi AKUNESA, vol.6, no.3.

Widiastuti, H., Koagouw, F.V. and Kalangi, J.S., (2018). Teknik Wawancara dalam Menggali Informasi pada Program Talk Show Mata Najwa Episode Tiga Trans 7. ACTA DIURNA KOMUNIKASI, 7(2).

Wiwik Rachmarwi, S.T., (2016). Evaluasi Strategi Bersaing Dalam Industri Hotel Studi Pada Hotel Sofyan Betawi. Jurnal Manajemen Bisnis Krisnadwipayana, 4(3).

Yin, R. K. (2019). Studi kasus desain \& metode. Jakarta: PT Raja Grafindo Persada.

Yuliani, W., (2018). Metode Penelitian Deskriptif Kualitatif Dalam Perspektif Bimbingan Dan Konseling. QUANTA, 2(2), pp.83-91.

\section{Profil Penulis}

Michelle Vebby Tanzil Salim adalah mahasiswa Program Studi Pariwisata, Fakultas Pariwisata, Unversitas Ciputra Surabaya angkatan 2016.

I Dewa Gde Satrya, Meraih gelar Sarjana Ekonomi pada 2004 dan Master Manajemen pada 2012 di Universitas Katolik Widya Mandala. Sebagai akademisi, saat ini sebagai dosen tetap Program Studi Pariwisata, Fakultas Pariwisata, Universitas Ciputra Surabaya sejak 2010. 
Mohamad Yusak Anshori. Meraih gelar Doktor Ilmu Ekonomi di Universitas Airlangga Surabaya dengan Predikat Cum Laude pada tahun 2009. Yusak menyelesaikan Program Magister Manajemen Stratejik (S2), Universitas Airlangga, Surabaya (2004) dan Sarjana Hubungan Internasional (S1), Universitas Gadjah Mada, Yogyakarta (1992). Sebagai akademisi saat ini sebagai dosen tetap Fakultas Ekonomi Bisnis dan Teknologi Digital Universitas Nahdlatul Ulama Surabaya (2016-Sekarang), juga sebagai Dosen Luar Biasa MM-UNAIR (2006-Sekarang) dan Dosen Luar Biasa MMT-ITS (2008-Sekarang) Serta sebagai Academic Advisory Board MM-UNAIR (2016Sekarang). Pernah Menjadi Dekan Fakultas Entrepreneurial Business Universitas Ciputra Surabaya (2011-2015) dan Dekan Fakultas Ekonomi Bisnis Universitas Nahdlatul Ulama Surabaya (2016-2021). 